\title{
The Role of Anions in the Formation of Multi-dimensional Coordination Polymers: Selective Separation of Anionic Toxic Dyes by 3D-Cationic Framework and Luminescent Properties
}

\author{
Kartik Maity and Kumar Biradha* \\ Department of Chemistry, Indian Institute of Technology, Kharagpur-721302, India \\ Fax:91-3222-282252; Tel: 91-3222-283346E-mail: kbiradha@chem.iitkgp.ernet.in
}

\section{Supporting Information}

Details of characterization of coordination polymers by IR spectra, PXRD and dye absorption and luminescence study. 
Table S1: Geometrical Parameters of Hydrogen Bonds in the complex 1-8

\begin{tabular}{|c|c|c|c|c|c|c|}
\hline Complex & Types & Donor (D) & $\begin{array}{c}\text { Acceptor } \\
\text { (A) }\end{array}$ & 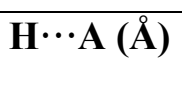 & $\mathbf{D} \cdots \mathbf{A}(\AA)$ & $\begin{array}{c}\text { D-H } \cdots A \\
\left({ }^{\circ}\right)\end{array}$ \\
\hline 1 & $\mathrm{~N}-\mathrm{H} \cdots \mathrm{F}$ & $\mathrm{N}(12)$ & $\mathrm{F}(100)$ & 1.90 & $2.744(6)$ & 165 \\
\hline 2 & $\mathrm{~N}-\mathrm{H} \cdots \mathrm{F}$ & $\mathrm{N}(12)$ & $\mathrm{F}(100)$ & 1.90 & $2.753(13)$ & 171 \\
\hline \multirow[t]{3}{*}{3} & $\mathrm{O}-\mathrm{H} \cdots \mathrm{O}$ & O1M & O21B & $1.98(3)$ & $2.811(4)$ & 179(4) \\
\hline & $\mathrm{N}-\mathrm{H} \cdots \mathrm{O}$ & $\mathrm{N} 12 \mathrm{~A}$ & O102 & 2.18 & $2.929(5)$ & 146 \\
\hline & $\mathrm{N}-\mathrm{H} \cdots \mathrm{O}$ & N12B & $\mathrm{O} 21 \mathrm{~A}$ & 2.07 & 2.918(3) & 170 \\
\hline \multirow[t]{2}{*}{4} & $\mathrm{~N}-\mathrm{H} \cdots \mathrm{S}$ & $\mathrm{N}(12 \mathrm{~A})$ & $\mathrm{S}(100)$ & 2.58 & $3.404(9)$ & 161 \\
\hline & $\mathrm{N}-\mathrm{H} \cdots \mathrm{O}$ & $\mathrm{N}(12 \mathrm{~B})$ & $\mathrm{O}(21 \mathrm{~A})$ & 2.09 & 2.944(9) & 174 \\
\hline \multirow[t]{4}{*}{5} & $\mathrm{~N}-\mathrm{H} \cdots \mathrm{O}$ & $\mathrm{N}(12 \mathrm{~A})$ & $\mathrm{O}(101)$ & 2.01 & $2.861(9)$ & 172 \\
\hline & $\mathrm{N}-\mathrm{H} \cdots \mathrm{O}$ & $\mathrm{N}(12 \mathrm{~B})$ & $\mathrm{O}(103)$ & 2.03 & $2.869(11)$ & 164 \\
\hline & $\mathrm{N}-\mathrm{H} \cdots \mathrm{O}$ & $\mathrm{N}(22 \mathrm{~A})$ & $\mathrm{O}(101)$ & 2.30 & $3.129(11)$ & 162 \\
\hline & $\mathrm{N}-\mathrm{H} \cdots \mathrm{O}$ & $\mathrm{N}(22 \mathrm{~A})$ & $\mathrm{O}(103)$ & 2.39 & $3.082(11)$ & 137 \\
\hline \multirow[t]{4}{*}{6} & $\mathrm{~N}-\mathrm{H} \cdots \mathrm{O}$ & N12A & $\mathrm{O} 3 \mathrm{~W}$ & 2.10 & $2.949(9)$ & 170 \\
\hline & $\mathrm{N}-\mathrm{H} \cdots \mathrm{O}$ & N12B & O101 & 1.95 & $2.805(7)$ & 169 \\
\hline & $\mathrm{N}-\mathrm{H} \cdots \mathrm{O}$ & $\mathrm{N} 22 \mathrm{~A}$ & O101 & 2.01 & $2.843(7)$ & 162 \\
\hline & $\mathrm{N}-\mathrm{H} \cdots \mathrm{O}$ & $\mathrm{N} 22 \mathrm{~B}$ & O104 & 2.02 & $2.854(7)$ & 164 \\
\hline \multirow[t]{2}{*}{7} & $\mathrm{~N}-\mathrm{H} \cdots \mathrm{O}$ & $\mathrm{N}(12)$ & $\mathrm{O}(32)$ & 1.94 & $2.760(5)$ & 158 \\
\hline & $\mathrm{N}-\mathrm{H} \cdots \mathrm{O}$ & $\mathrm{N}(22)$ & $\mathrm{O}(31)$ & 2.02 & $2.861(5)$ & 166 \\
\hline 8 & $\mathrm{~N}-\mathrm{H} \cdots \mathrm{O}$ & $\mathrm{N}(12 \mathrm{~A})$ & $\mathrm{O}(21 \mathrm{~B})$ & 2.15 & $2.937(4)$ & 152 \\
\hline
\end{tabular}




\section{FTIR of CPs of 1 to 8:}

IR spectra of $\mathbf{1}$ :

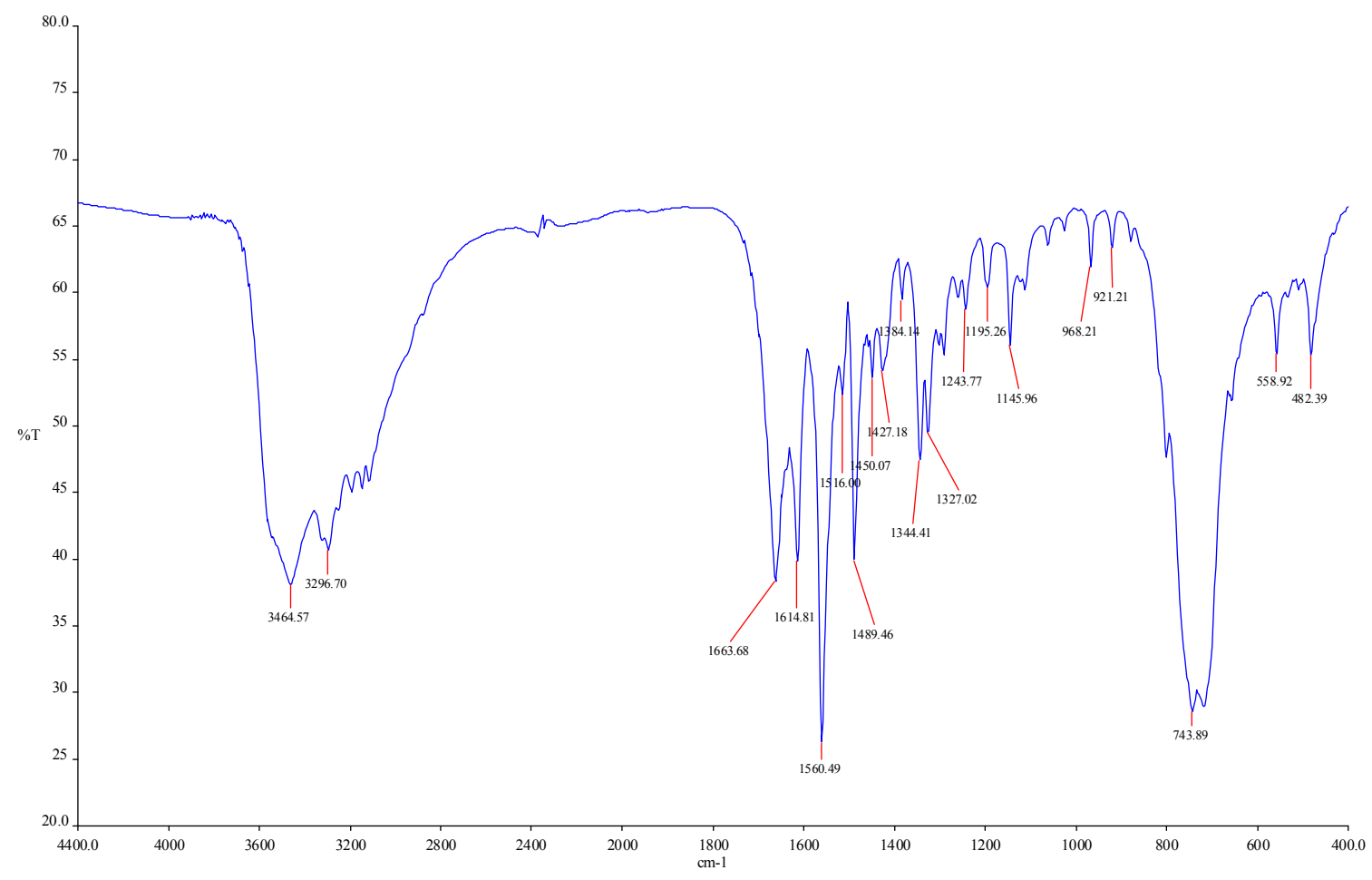

IR spectra of 2:

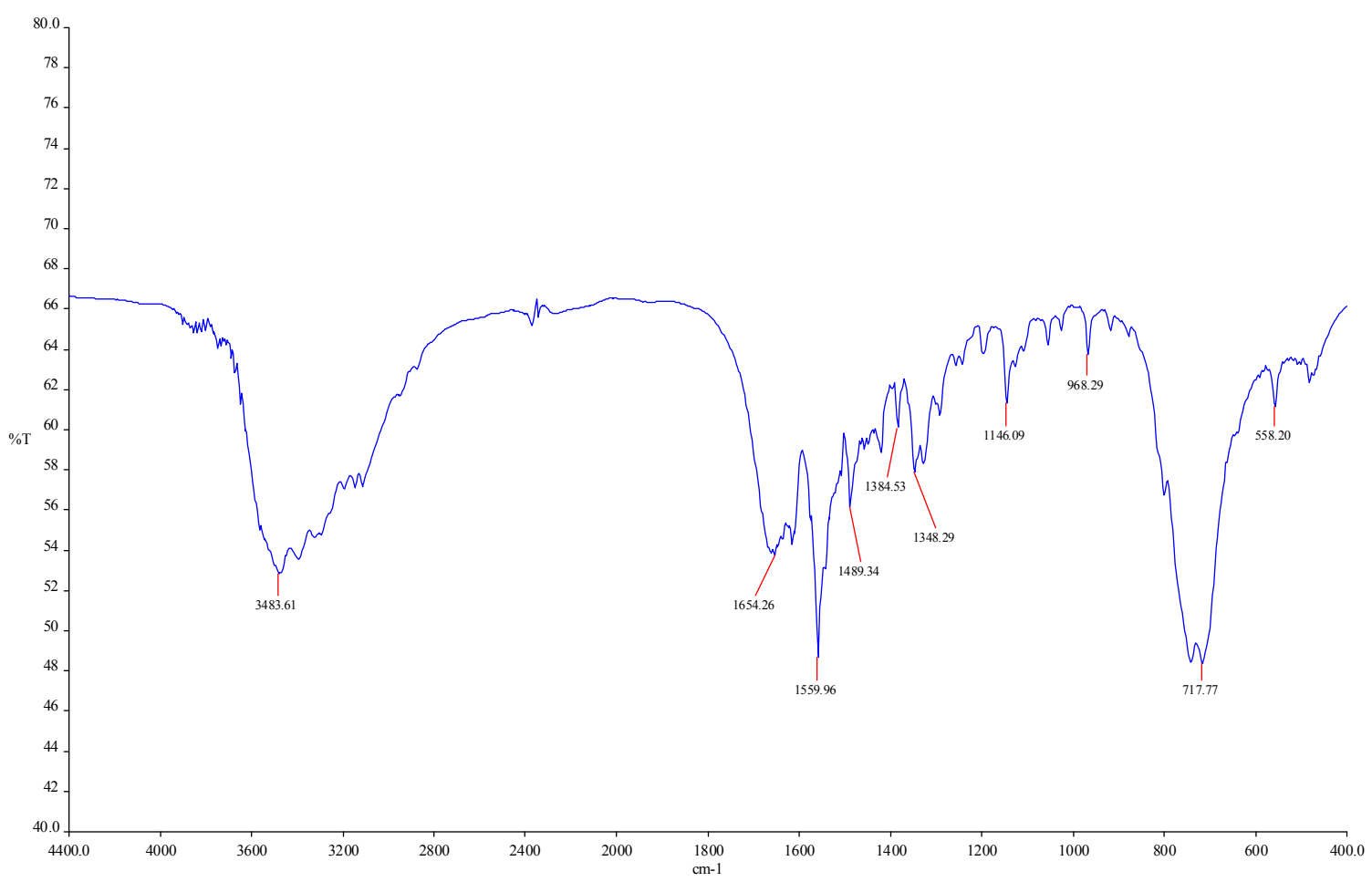




\section{IR spectra of 3:}

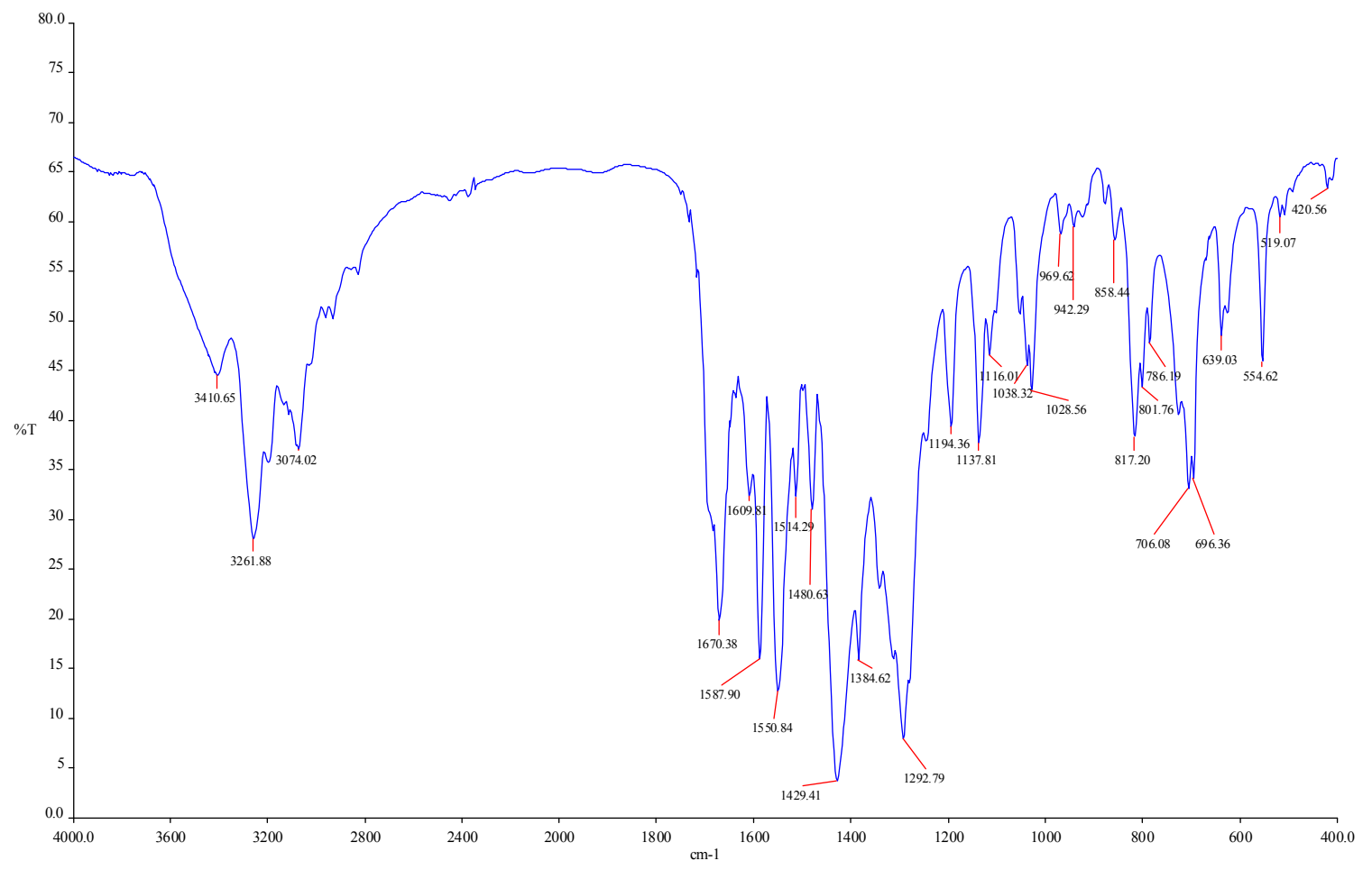

\section{IR spectra of 4:}

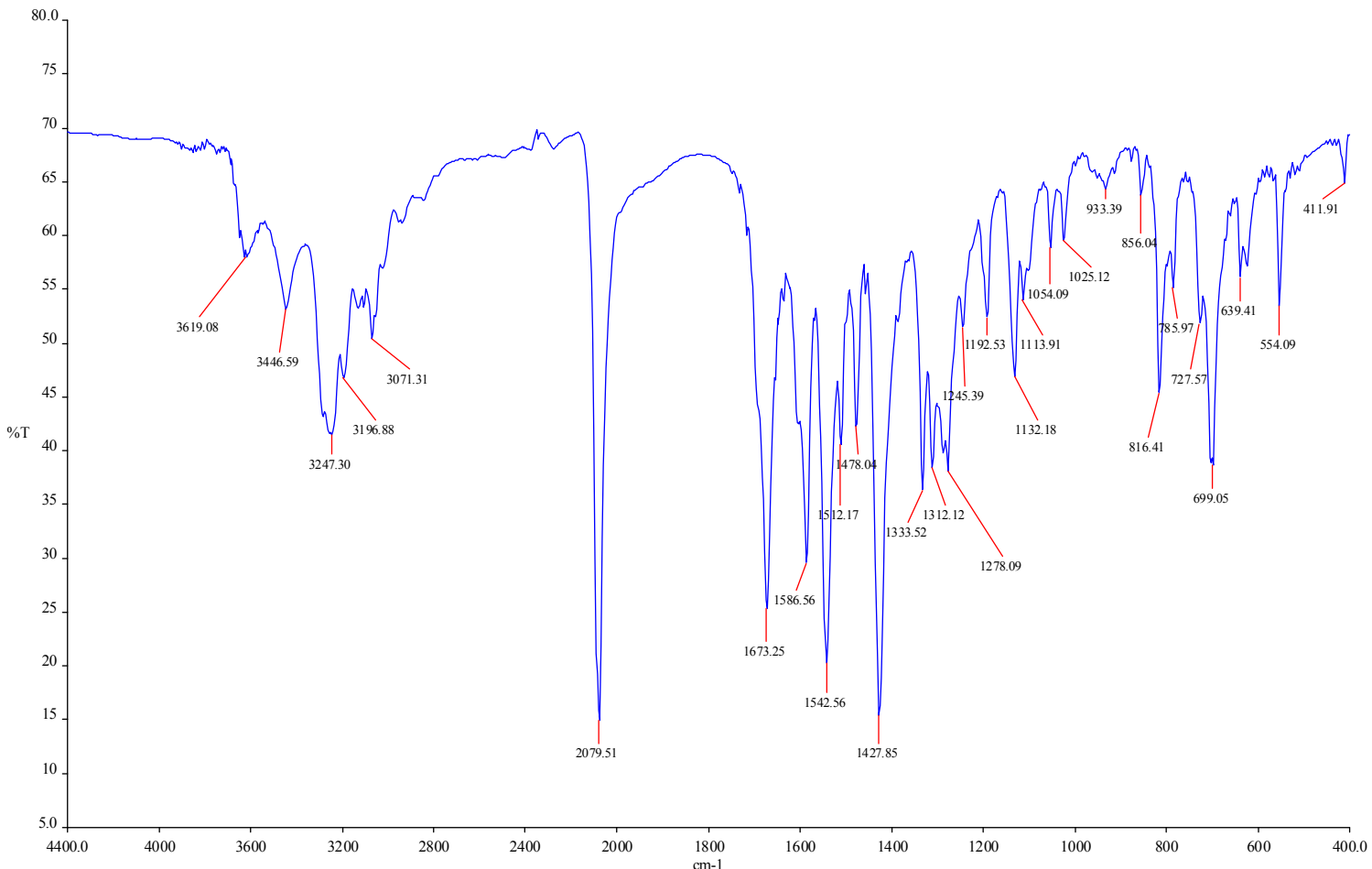


IR spectra of $\mathbf{5}$ :

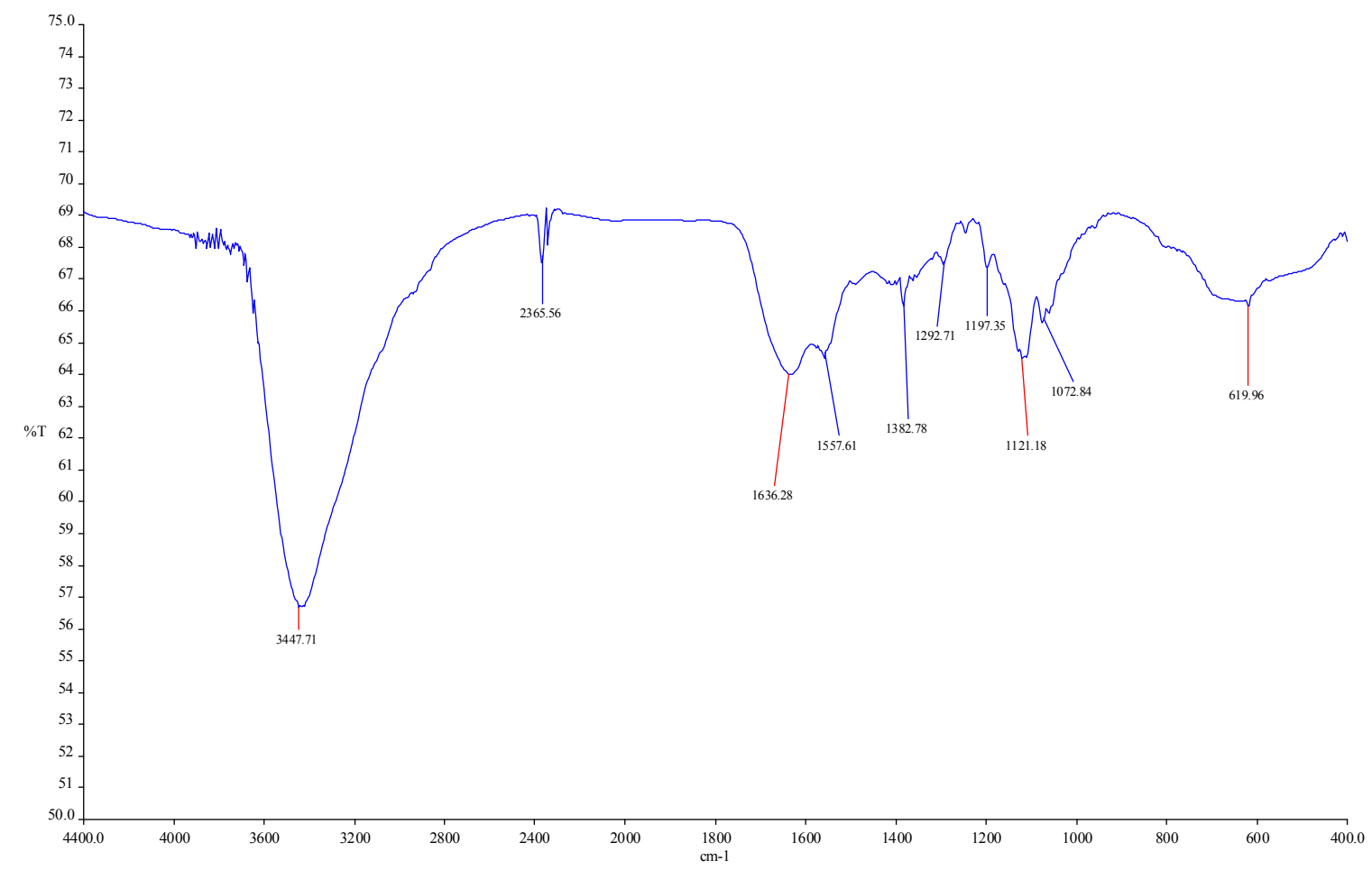

IR spectra of $\mathbf{6}$ :

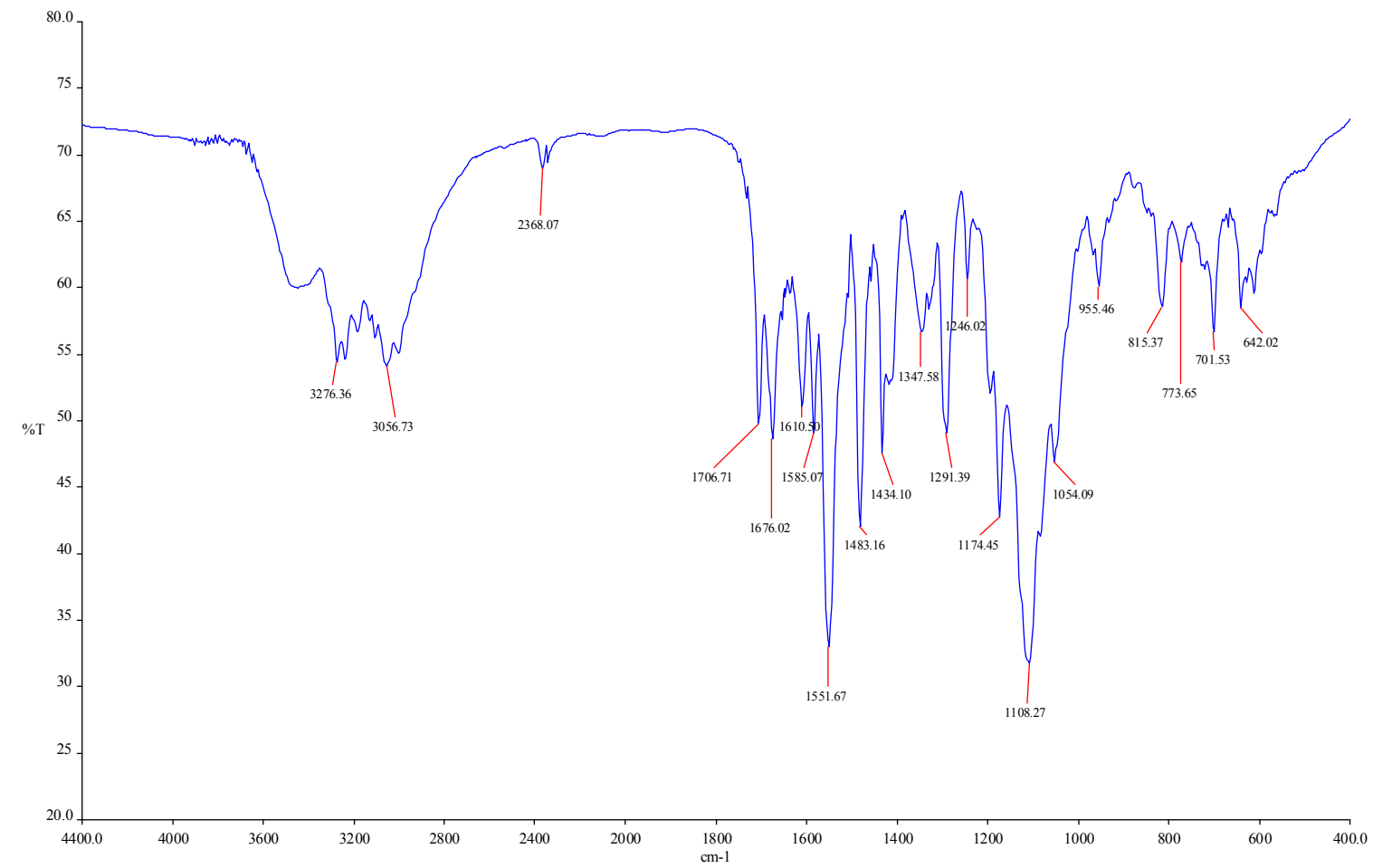


IR spectra of 7:

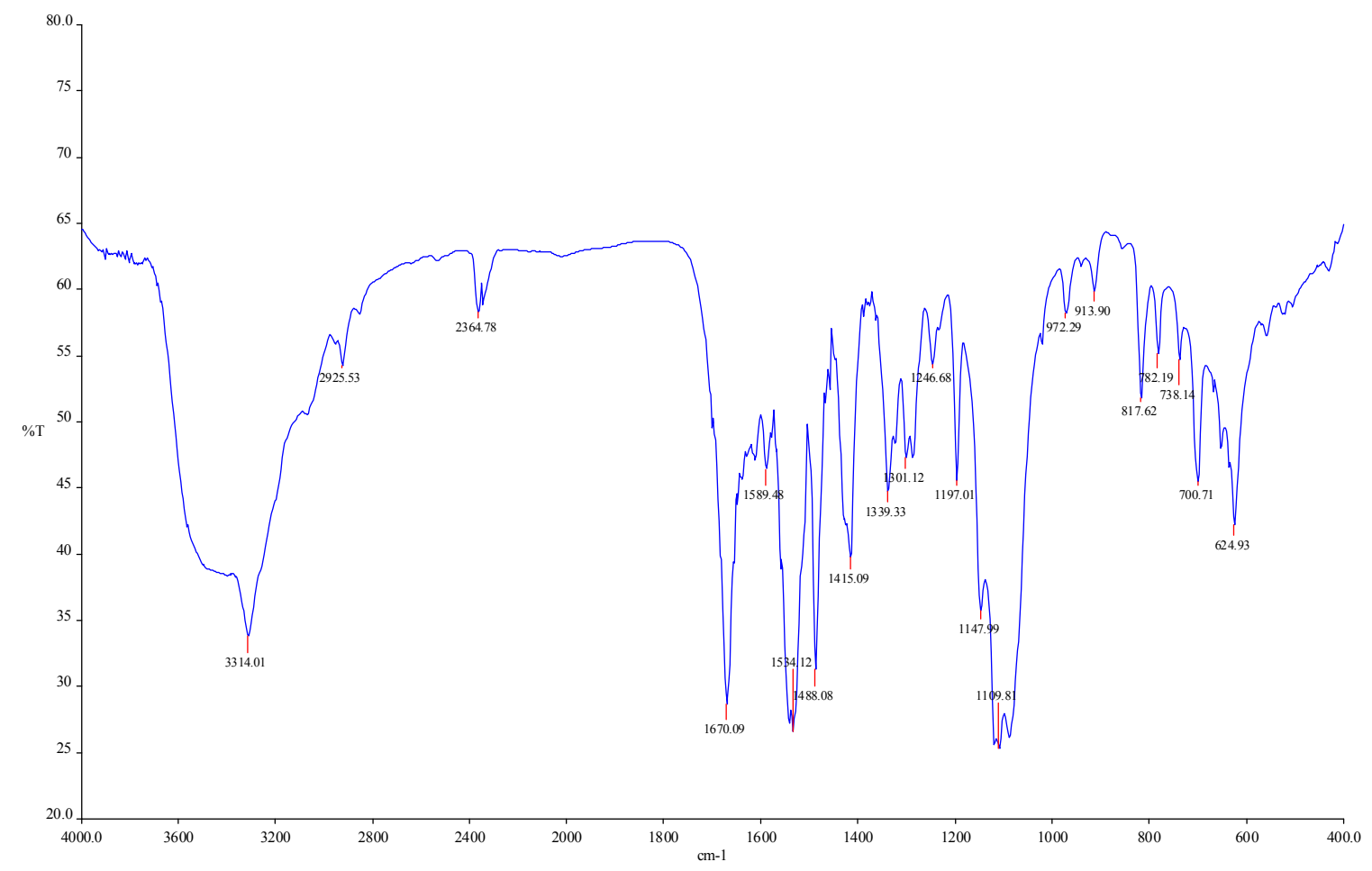

IR spectra of $\mathbf{8}$ :

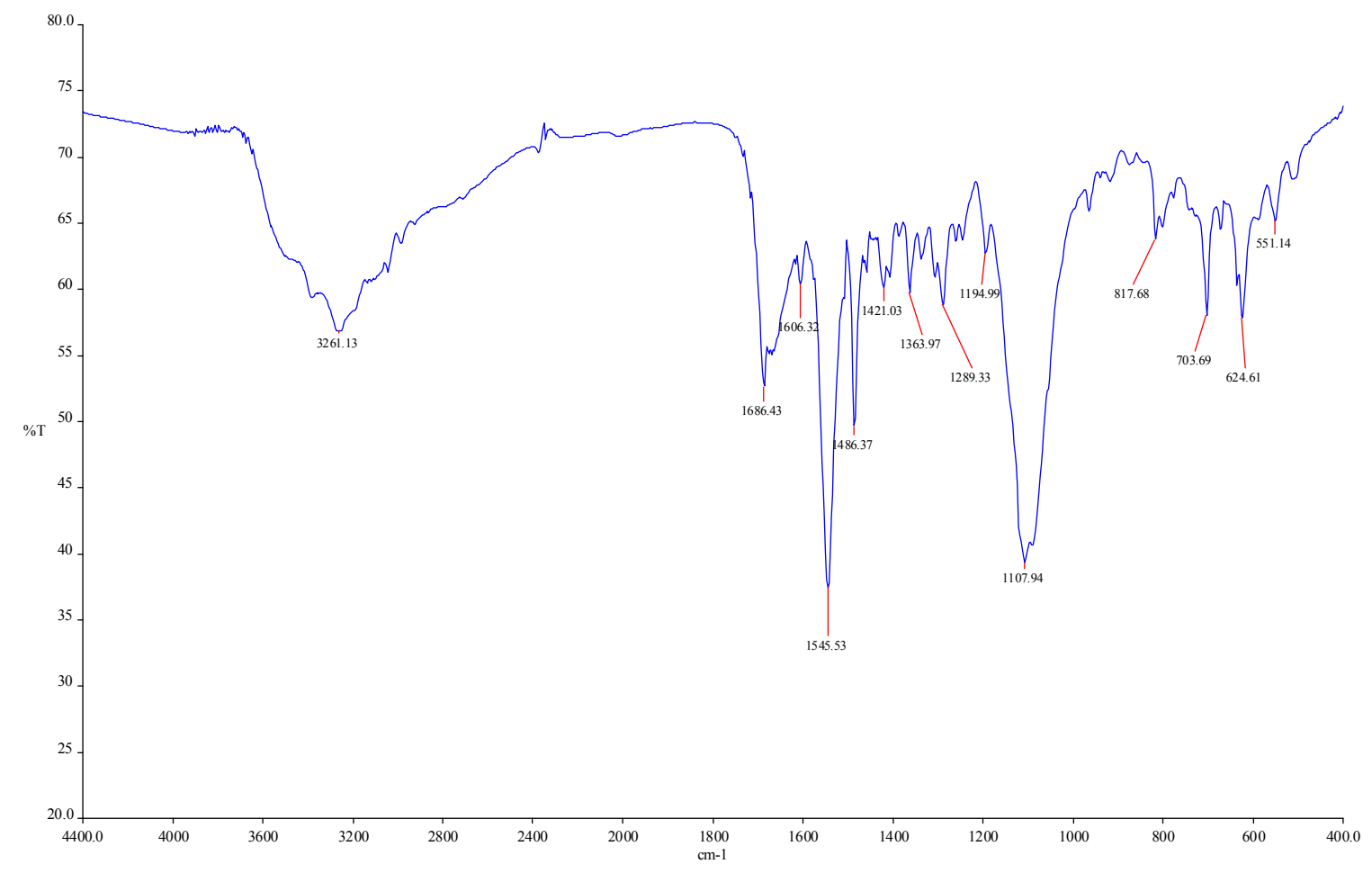


Calculated and experimental PXRD patterns for 1-8; 8 and 8a:

Complex 1

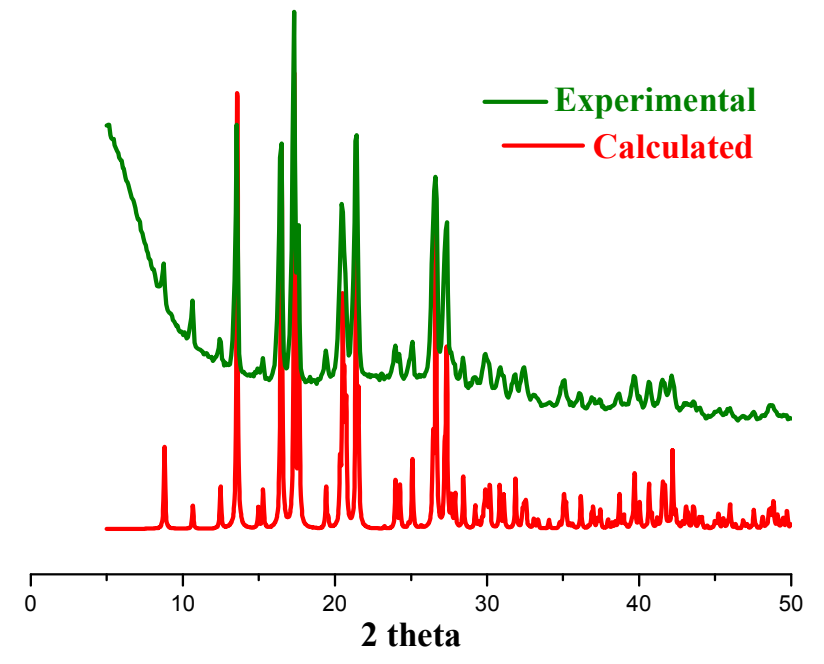

Complex 2

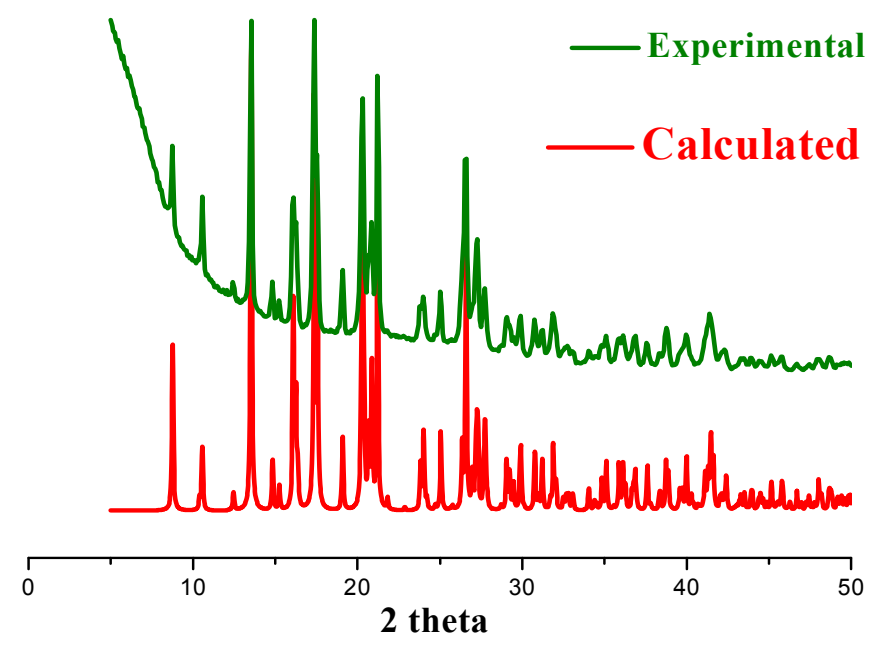


$\underline{\text { Complex } \mathbf{3}}$

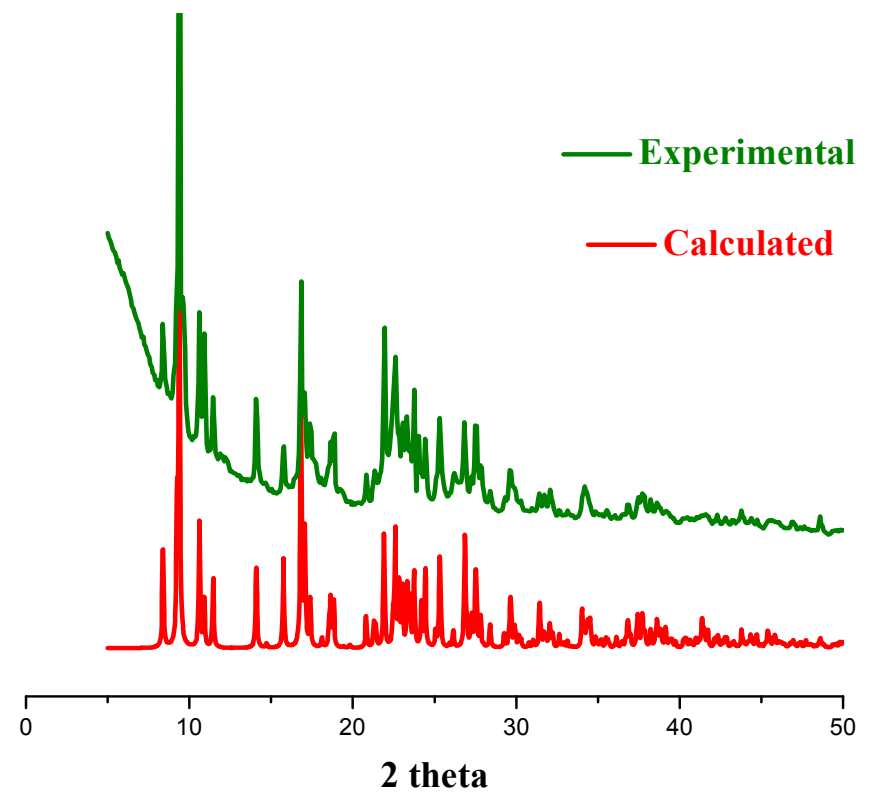

Complex 4

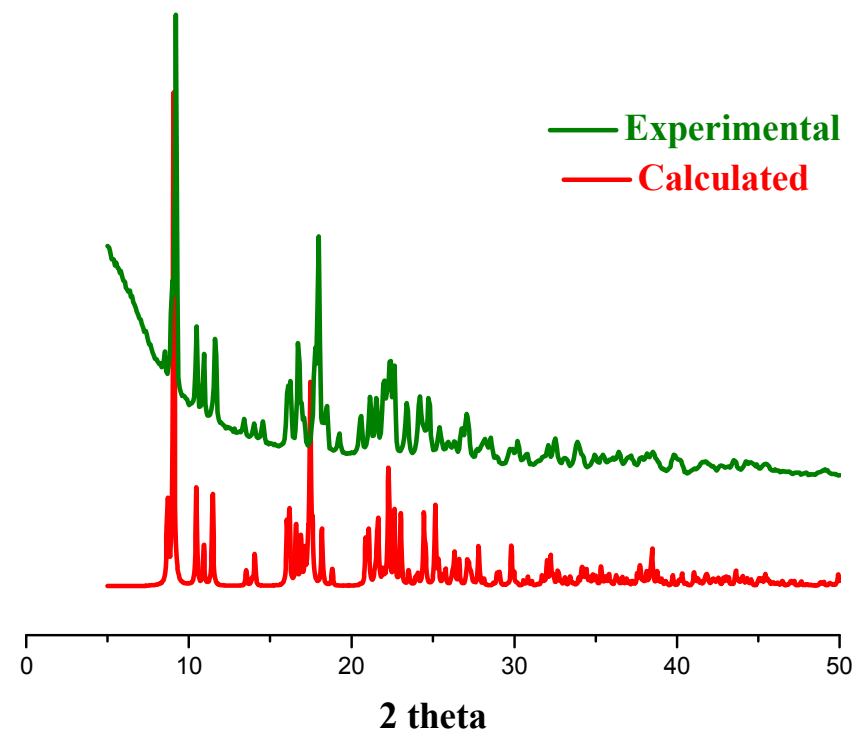


Complex 5

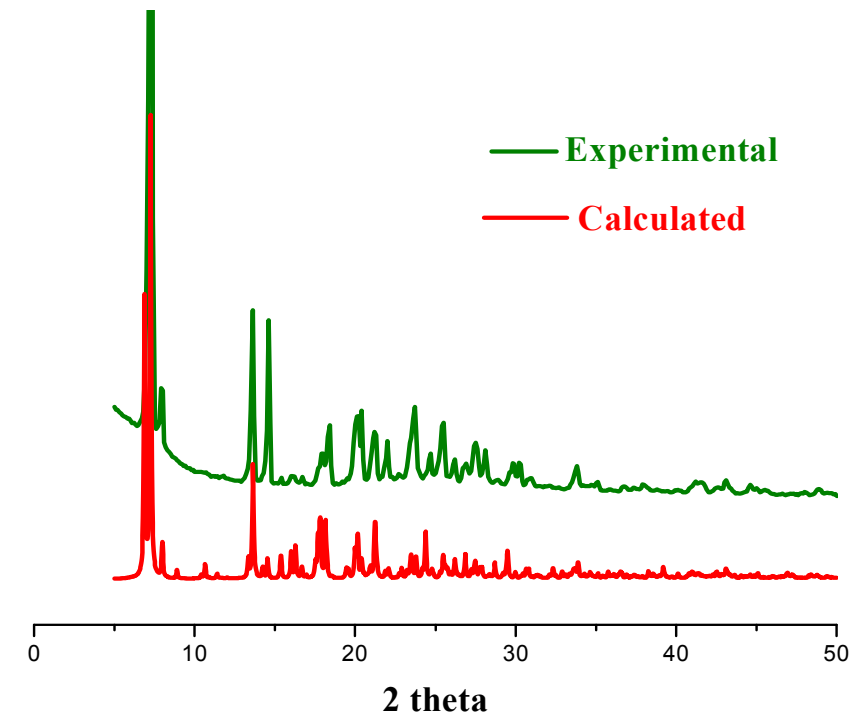

$\underline{\text { Complex } 6}$

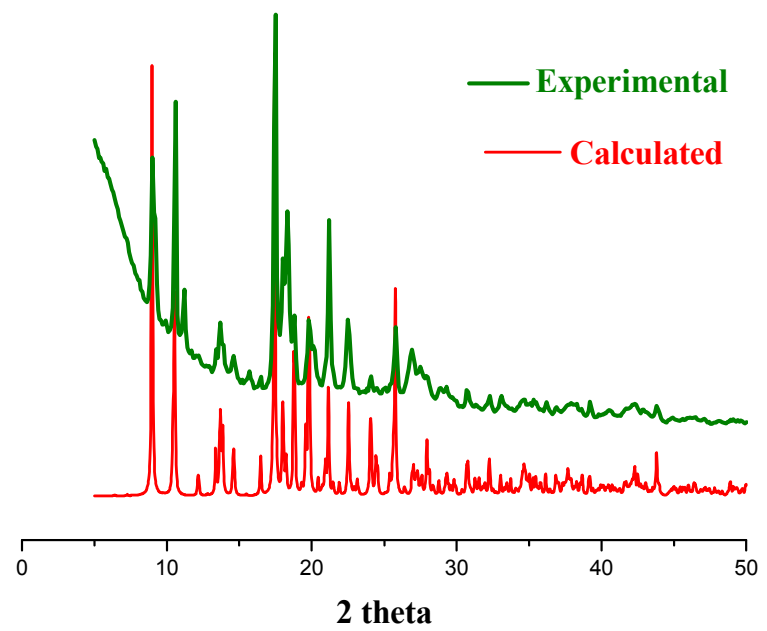


Complex 7

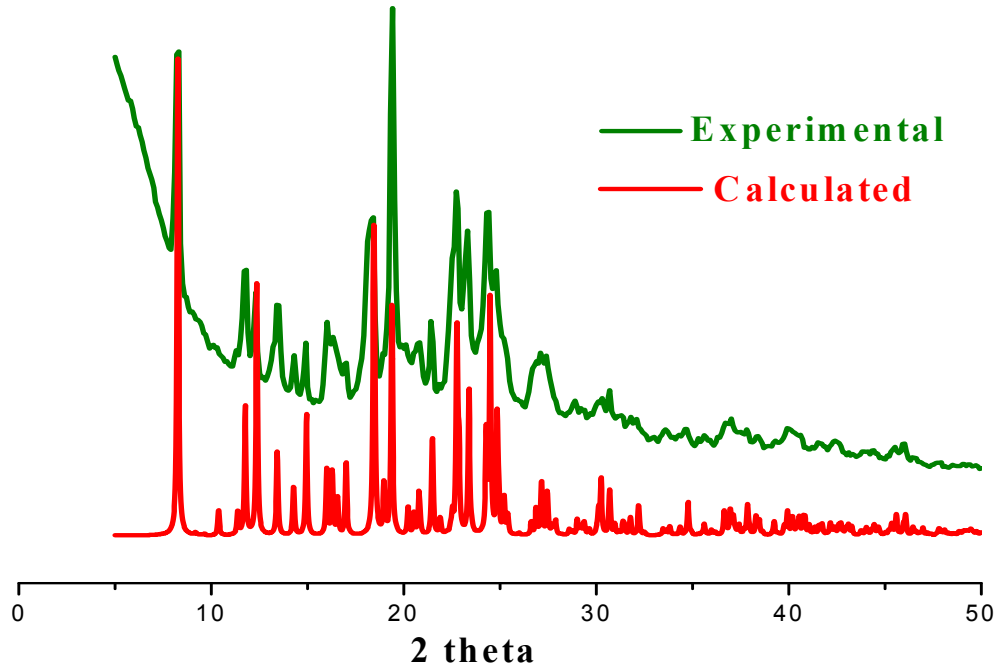

$\underline{\text { Complex } 8}$

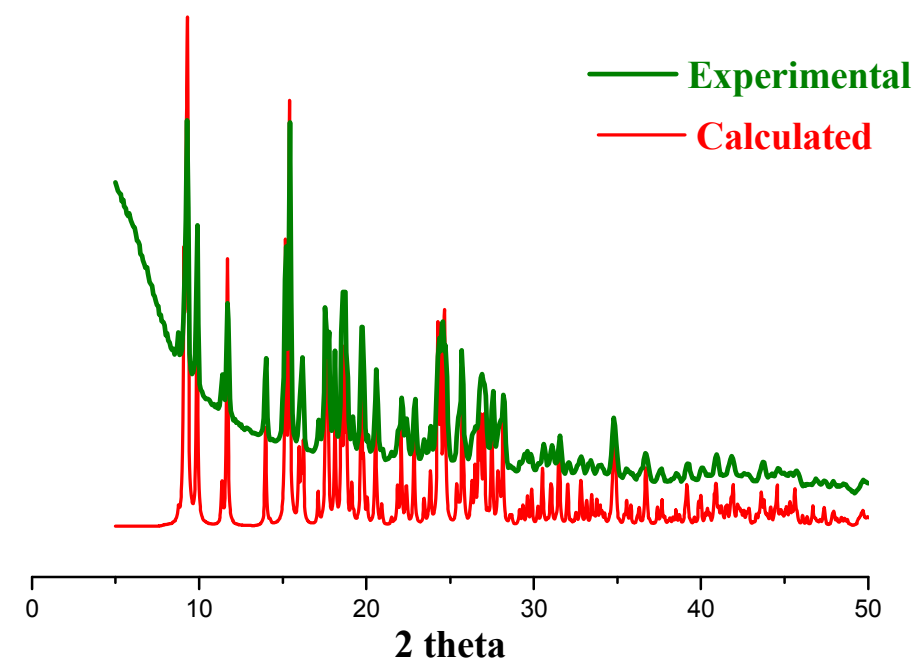


Complex 8 and FSD adsorbed complex 8(8a)
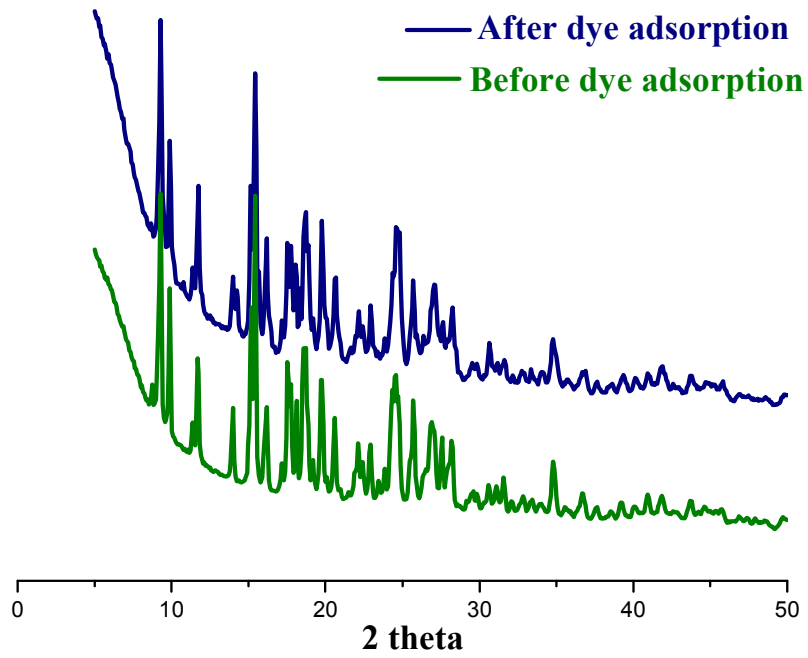
Blank UV curves of the dyes in aqueous solution:

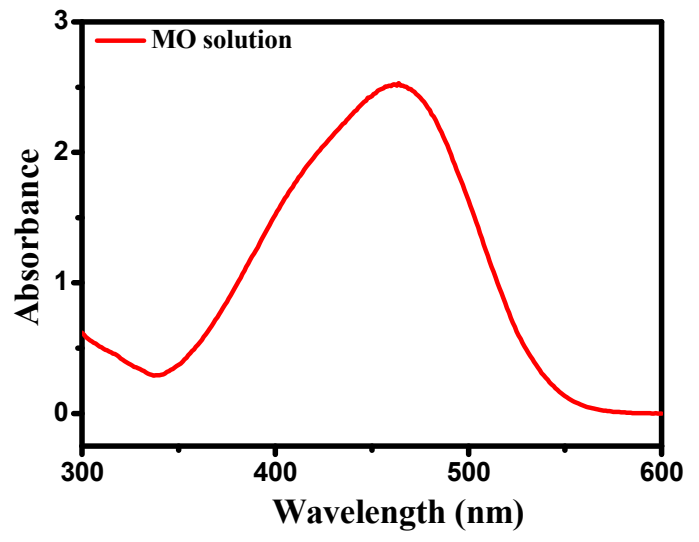

$\mathrm{MO}$ in aqueous solution

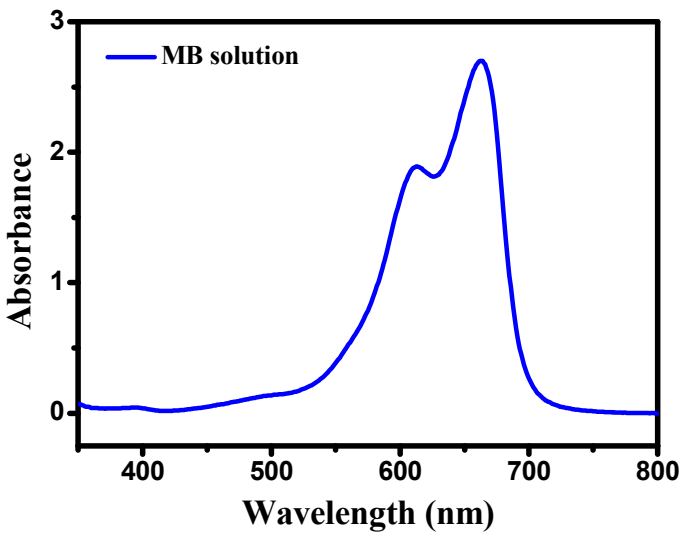

$\mathrm{MB}$ in aqueous solution

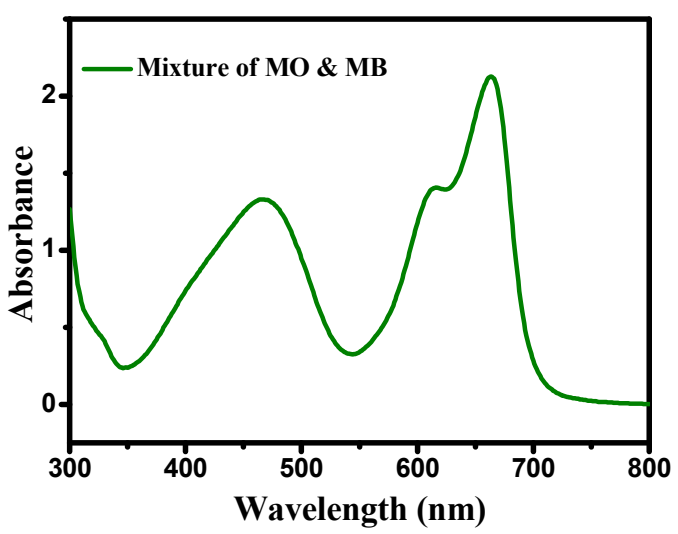

Mixture of MO \& MB in aqueous solution

Solid state UV- visible spectrum of 8:

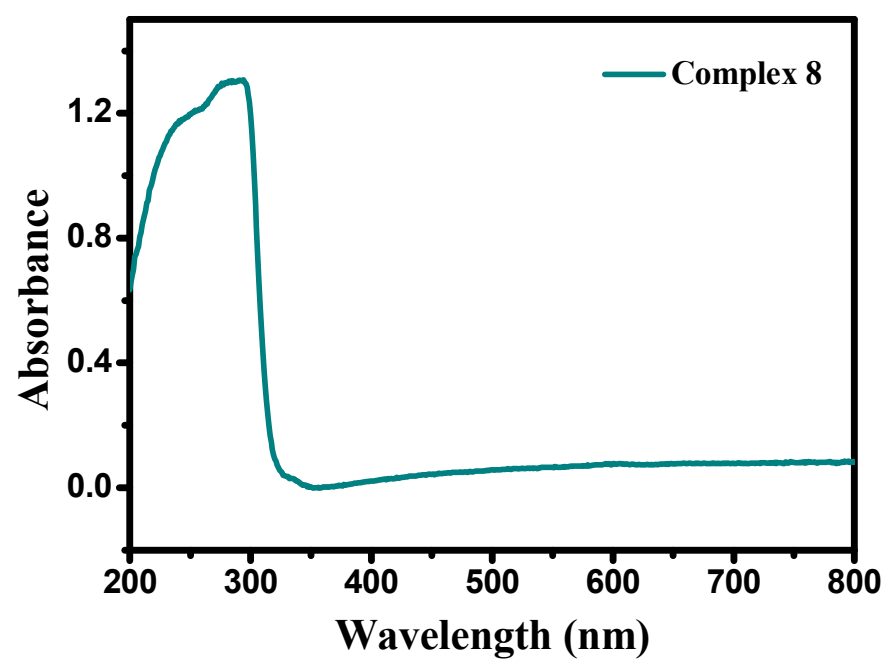


Solid state luminescence emission profile of the dye doped 8a prepared at different concentration of dye in aqueous solution:

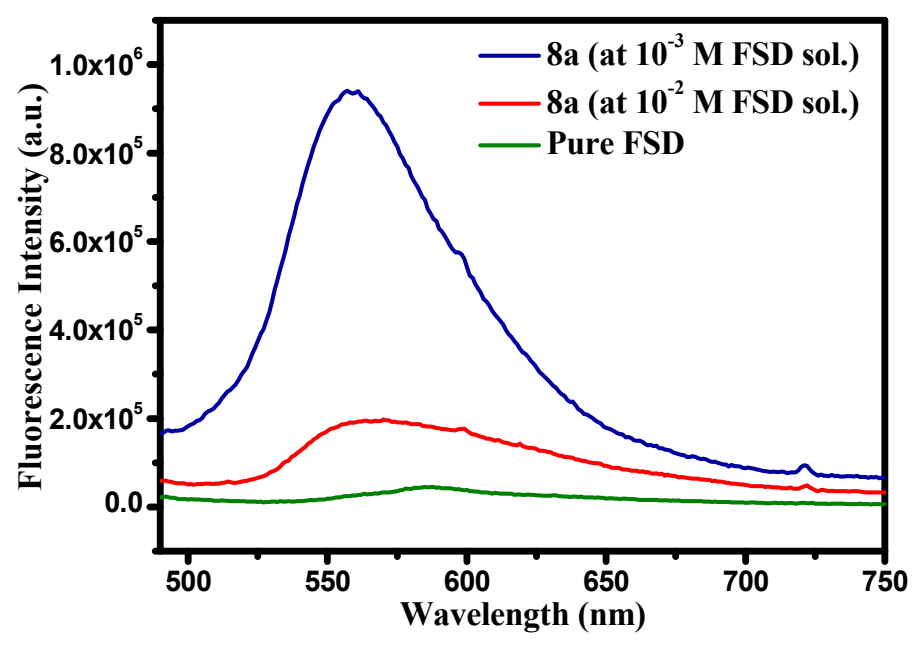




\section{Calculation of maximum amount of MO that can be adsorbed by 8:}

$$
q_{e}=\left(\frac{C_{0}-C_{e}}{m}\right) V
$$

Where,

$\mathrm{q}_{\mathrm{e}}$ is the amount of $\mathrm{MO}$ in $\mathrm{mg}$, adsorbed onto $1 \mathrm{~g}$ adsorbent,

$\mathrm{C}_{0}$ and $\mathrm{C}_{\mathrm{e}}$ are the initial and equilibrium concentrations of $\mathrm{MO}$ in solution $(\mathrm{mg} / \mathrm{L})$,

$\mathrm{V}$ is the volume of solution (L),

$\mathrm{m}$ is the mass of adsorbent $(\mathrm{g})$.

$10 \mathrm{mg}$ crystals of 8 were immersed in the $20 \mathrm{ml} 10^{-4}(\mathrm{M})$ aqueous solution of $\mathrm{MO}$ and kept in dark. After the complete of adsorption process, absorbance of equilibrium concentrations of $\mathrm{MO}$ in solution were measured.

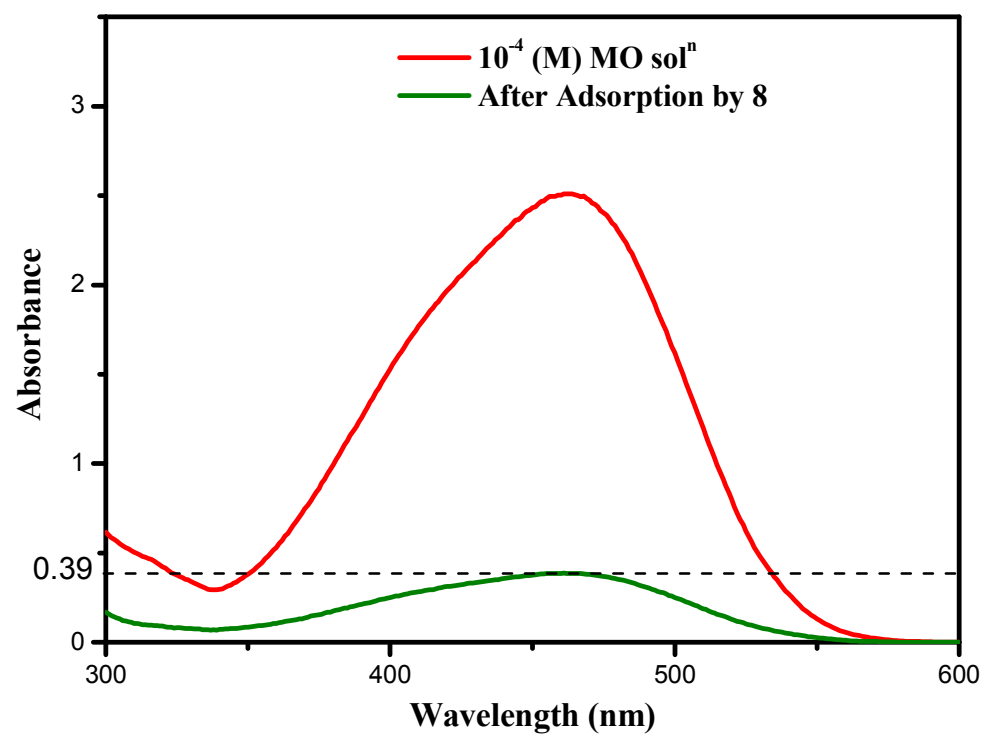

$\mathrm{C}_{0}=10^{-4}(\mathrm{M})$

$\mathrm{C}_{\mathrm{e}}=$ Can be calculated using the Beer-Lambert law. $[\mathrm{A}=\varepsilon \mathrm{cl}]$ 
The molar extinction coefficient, $\varepsilon$ can be calculated by using a known concentration $\mathrm{MO}$ solution, $10^{-5}(\mathrm{M})$.

According to the Beer-Lambert law,

$\mathrm{A}=\varepsilon \mathrm{cl}$

$\mathrm{A}=$ absorbance of the materials

$\varepsilon=$ molar extinction coefficient

$\mathrm{c}=$ concentration of the solution

$1=$ path length

Therefore,

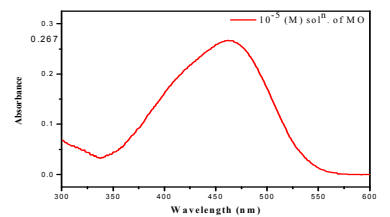

$\varepsilon=\mathrm{A} /(\mathrm{cl})$

again, $\mathrm{A}=0.267$ and $\mathrm{c}=10^{-5}(\mathrm{M})$

So,

$\varepsilon=0.267 /\left(10^{-5} 1\right)$

Again,

$$
\begin{array}{lll}
\mathrm{C}_{\mathrm{e}}=\mathrm{A}_{\mathrm{e}} /\left(\varepsilon_{\mathrm{e}} \mathrm{l}\right) \text { and } \quad \mathrm{A}_{\mathrm{e}}=0.39 \quad & \varepsilon=0.267 /\left(10^{-5} 1\right) \\
& \text { or, } \varepsilon \mathrm{l}=0.267 / 10^{-5}
\end{array}
$$

$$
\begin{aligned}
\mathrm{C}_{\mathrm{e}} & =\mathrm{A}_{\mathrm{e}} /\left(\varepsilon_{\mathrm{e}} \mathrm{l}\right) \\
\text { or, } \mathrm{C}_{\mathrm{e}} & =0.39 /\left(0.267 / 10^{-5}\right) \\
\text { or, } \mathrm{C}_{\mathrm{e}} & =(0.39 / 0.267) 10^{-5}(\mathrm{M}) \\
\text { or, } \mathrm{C}_{\mathrm{e}} & =1.46067 \times 10^{-5}(\mathrm{M}) \\
\text { or, } \mathrm{C}_{\mathrm{e}} & =0.146067 \times 10^{-4}(\mathrm{M}) \\
\mathrm{C}_{0} & =10^{-4}(\mathrm{M}), \\
= & 327.33 \times 10^{-4} \times 10^{3} \mathrm{mg} / \mathrm{L} \\
= & 32.733 \mathrm{mg} / \mathrm{L}
\end{aligned}
$$




$$
\begin{aligned}
\mathrm{C}_{\mathrm{e}} & =0.146067 \times 10^{-4}(\mathrm{M}), \\
& =0.146067 \times 327.33 \times 10^{-4} \times 10^{3} \mathrm{mg} / \mathrm{L} \\
& =4.781 \mathrm{mg} / \mathrm{L}
\end{aligned}
$$

$$
\begin{array}{rlrl}
\mathrm{C}_{0}-\mathrm{C}_{\mathrm{e}} & =(32.733-4.781) \mathrm{mg} / \mathrm{L} \quad \mathrm{m}=0.01 \mathrm{~g} \quad \mathrm{~V}=0.02 \mathrm{~L} \\
& =27.952 \mathrm{mg} / \mathrm{L} &
\end{array}
$$

Therefore,

$$
\begin{gathered}
q_{e}=\left(\frac{C_{0}-C_{e}}{m}\right) V \\
\mathrm{q}_{\mathrm{e}}=(27.952 \times 0.02) /(0.01)[\{(\mathrm{mg} / \mathrm{L}) \times \mathrm{L}\} / \mathrm{g}] \\
\mathrm{q}_{\mathrm{e}}=55.904 \mathrm{mg} / \mathrm{g}
\end{gathered}
$$

